\title{
Pedagogical performance in the preschool teaching of students with Autism Spectrum Disorder
}

\author{
Eduardo Pimentel da Rocha ${ }^{1}$ \\ https://orcid.org/0000-0002-9937-7806 \\ Amanda Tragueta Ferreira-Vasques ${ }^{1}$ \\ https://orcid.org/0000-0003-0489-3611 \\ Dionísia Aparecida Cusin Lamônica1 \\ https://orcid.org/0000-0002-9381-0680
}

Universidade de São Paulo, Faculdade de Odontologia de Bauru - FOB/USP, Bauru, São Paulo, Brasil.

Research support source: Coordenação de Aperfeiçoamento de Pessoal de Nível Superior - Brasil (CAPES) - Financial Code 001.

Conflict of interests: Nonexistent

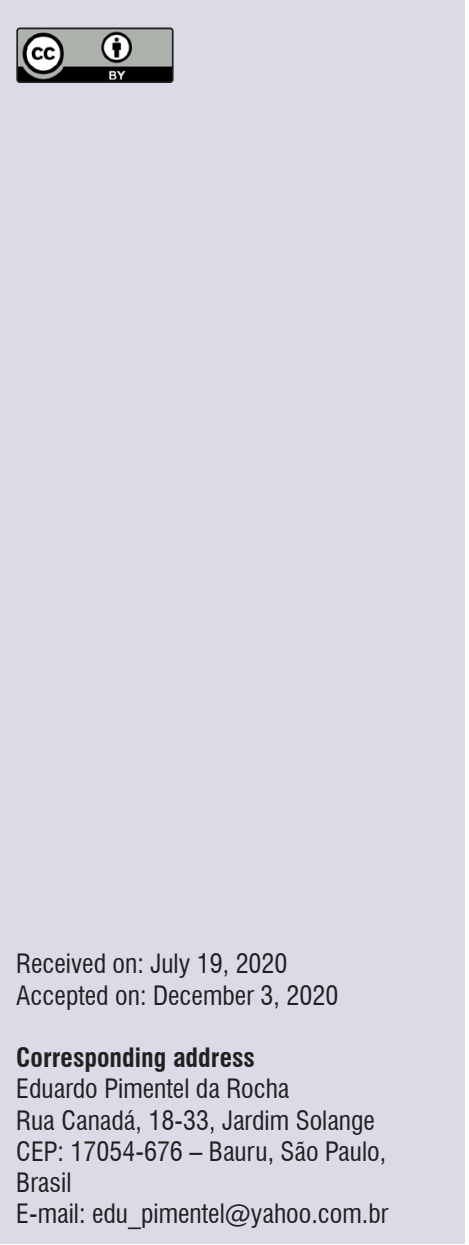

\section{ABSTRACT}

Purpose: to describe the panorama of the pedagogical context in the preschool teaching of students with Autism Spectrum Disorder (ASD), in a municipality in the state of São Paulo, Brazil.

Methods: 32 teachers, including early childhood education (ECE), special education (SE), and specialized educational assistance (SEA), participated answering a questionnaire about their performance with autistic students. A descriptive qualitative analysis of the data was performed.

Results: the average age of the teachers was 40.6 years old, with an undergraduate degree in Teaching, Pedagogy, Special Education, and/or Visual Arts, of which $84.4 \%$ were postgraduate. $87.4 \%$ knew ASD characteristics; $80 \%$, SEA, $66.7 \%$, SE, 57.1\% of ECE teachers had receive the medical report. $78.1 \%$ reported difficulties in socialization, communication, behavior, learning; 15.6\%, aggressive behavior / irritation; $12.5 \%$, difficulties in attention / concentration; $6.2 \%$, motor coordination difficulties in their autistic students. $62.5 \%$ considered that their autistic students had the potential to follow mainstream education; $68.8 \%$ received guidance from team professionals; $78.1 \%$ participated in courses/lectures on the theme; $28.1 \%$ considered they were able to teach autistic children; $78.1 \%$ stated that adjustments in the teaching structure were necessary.

Conclusion: the scenario of the pedagogical context in the preschool teaching of students with ASD, in the studied municipality, needs reflections. Information on ASD characteristics, training courses, knowledge on individual follow-ups, so that teachers are prepared to promote effective teaching and learning, are needed.

Keywords: Teaching; Autism Spectrum Disorder; Education 


\section{INTRODUCTION}

The movement for social, economic, and school inclusion of people with Autism Spectrum Disorder (ASD) in Brazil has strengthened in recent decades and occurred as a response to the State's failure to develop its role in guaranteeing rights for this population ${ }^{1,2}$.

Regarding education, the legislations for school inclusion in Brazil, developed from the Brazilian Federal Constitution of of $1988^{3}$ (instituted the equality of all before the law and recognized the need to guarantee rights for all Brazilian citizens, without discrimination by color, race, religion, political opinion, among other factors), once influenced by ideological changes on the international scenario and the new look at the social role of people with ASD, began to consider the difference as natural to human existence. Thus, those formerly supporting actors also became main players in the public policies scenario of Brazilian education, influencing the development of a new school model, the inclusive one ${ }^{4}$.

The inclusive school, which foresees the development of everyone in an environment in which diversity is contemplated, being it an irreplaceable part and common to human relations, has become increasingly present in school thinking and doing on the national scenario ${ }^{5}$. Regarding the inclusive model, it is proposed that schools governed by this model "constitute the most capable means to combat discriminatory attitudes, building an inclusive society and reaching education for all"'.

In the political and social sphere, the inclusive model has been incorporated into the development of public policies, such as the National Policy of Special Education In the Inclusive Education Perspective ${ }^{7}$, which aims to build policies that can promote quality education to all students; the National Policy for the Protection of the Rights of the Person with Autism Spectrum Disorder ${ }^{8}$, which protects the rights of people with ASD, enabling their social and personal development; and the Brazilian Law for the Inclusion of Persons with Disabilities ${ }^{9}$, which foresees the need of strategies that ensure and promote conditions for the development of citizenship of people with disabilities in all social spheres.

The development and strengthening of these policies have enabled the exponential growth in the numbers of enrollment of children with various degrees of $A D^{10}$ in mainstream schools across the country in recent years, indicating a positive aspect of effectiveness of these policies in Brazil, regarding the school inclusion of these students.

On the other hand, recent researches have questioned the real effectiveness of inclusive policies in Brazil, alleging that investments in the qualitative aspects of education for these children are still low and have not come in number and proportion to follow the expansion of educational access and that education in Brazil has been treated only with an electoral bias, being the educational indices presented internationally not consistent with the reality experienced in the country ${ }^{11-14}$. Thus, "in the face of this new scenario, Brazilian researchers intensified their search for the factors that determine quality schools and that positively influence teaching and student performance" ${ }^{15}$.

Considering that ASD is a neurodevelopmental disorder, in which the child may present linguistic and communicative deficits, social and restrictive, repetitive and/or stereotyped behaviors ${ }^{16}$, investment in qualitative aspects, such as teacher education, development of methodologies, teaching materials, technology, and curricula, as foreseen by law ${ }^{17}$, are fundamental for the provision of quality education and the promotion of their academic success since the first years of school life.

Knowing that the pedagogical performance of teachers is an important qualitative aspect to promote the school success of children with ASD, it is worth reflecting on the pedagogical performance developed with this population ${ }^{18-20}$. Thus, this study aimed to describe the panorama of the pedagogical context in the preschool education of students with Autism Spectrum Disorder, in a city in the state of São Paulo, Brazil.

\section{METHODS}

Following ethical aspects, approval of the Research Ethics Committee on Human Beings of the Bauru Dentistry School of the University of São Paulo, Brazil, under number 2.332.814; of the Center for Professional Improvement of Municipal Education (NAPEM) of the Bauru Municipal Education Office, São Paulo; and of the Support Center for School Inclusion (CAIE) of the Association of Parents and Friends of the Exceptional Children (APAE), of the studied city, was obtained.

Seven public municipal mainstream schools from different regions of Bauru, the interior of São Paulo, were contacted and invited to participate in the research, as well as the CAIE of the APAE of Bauru, which has an agreement with the Bauru Municipal Education Office 
for development of educational assistance of special education students regularly enrolled in preschools in the city. The study was developed between 2018 and 2019.

With the acquiescence letters from the seven schools and CAIE, teachers who met the inclusion criteria and agreed to participate in the research signed the Informed Consent Form and fill out a self-administered questionnaire divided into two blocks.

For data collection, and for the convenience of teachers, the researchers went to the seven schools and CAIE, at a time and day scheduled with the participants. The teachers were first instructed about the purpose of the research and doubts were clarified. The questionnaire was presented to the teachers and its fulfilling took 15 minutes, on average.

The inclusion criteria applied to the study participants were: to be a teacher in the preschool context; teach individuals with ASD; work in the municipality of Bauru. 32 teachers participated in the study, 27 from the seven schools and five from CAIE.

The questionnaire (ATTACHED) and the questions were elaborated considering the objective of the research, the authors' prior knowledge of the target audience, and the investigated context. The authors sought to understand the factors directly and/or indirectly involved in the pedagogical performance of teachers and how they may or may not influence these practices and contribute to the quality of education of children with ASD in the investigated municipality. The questionnaire was created exclusively for this study and was composed of 15 open and closed questions, distributed in Blocks 1 and 2, related to personal data, education, performance of teachers and the knowledge and observation of development characteristics of their student (s) with ASD.

Block 1 of the questionnaire refers to the characterization of the teacher in terms of personal data, academic background, and current teaching context, containing six questions. Block 2, with nine questions, includes questions that aim to understand the factors directly and/or indirectly involved in the pedagogical performance of teachers with their students with ASD.

It is noteworthy that, only for question 1 of Block 2, a classification from 1 to 4 of the participants' answers about their knowledge about the characteristics of ASD was elaborated by the authors to facilitate the analysis of these data, in which 4 represented the knowledge of the main characteristics of ASD described in DSM-5 (deficits in communication; alteration in social interaction; restricted and/or repetitive patterns of behavior and interest) by the teachers and 1 represented the non-citation of any of the basic characteristics of ASD.

The data were analyzed in a descriptive qualitative manner, without the use of statistical tests.

\section{RESULTS}

\section{BLOCK 1 - Participant Characterization}

The 32 study participants (100\%), teachers, were females, with an average age of 40.6 years, with 28 years being the minimum age and 58 years the maximum age. Teachers had an undergraduate degree in the following areas: Teaching, Pedagogy, Special Education, and Visual Arts (Chart 1). It was acceptable to point out more than one degree, which occurred with 2 participants who had a degree in both teaching and pedagogy.

Chart 1. Distribution of the teachers by academic area

\begin{tabular}{|l|c|c|}
\hline Undergraduate degree & Participants & Percentage \\
\hline Teaching & 4 & $12.12 \%$ \\
\hline Pedagogy & 28 & $87.5 \%$ \\
\hline Special Education & 1 & $3.03 \%$ \\
\hline Visual Arts & 1 & $3.03 \%$ \\
\hline
\end{tabular}


Concerning a postgraduate degree, $84.4 \%(n=27)$ of the teachers had some type of course in the modality (latu sensu); while $15.6 \%(n=5)$ did not have it. Of the teachers who are not postgraduate students, all worked in mainstream preschool.

As for the teaching context, $65.6 \%(n=21)$ of the teachers worked in Early Childhood Education (ECE), $18.8 \%(n=6)$ in Special Education (SE) and 15.6\% $(n=5)$ in Specialized Educational Assistance (SEA).

\section{BLOCK 2 - Performance with students with Autism Spectrum Disorder}

When questioned about their knowledge about the characteristics of ASD, $84.4 \%(n=27)$ answered positively and only $15.6 \%(n=5)$ of the teachers answered that they did not know these characteristics, all of them working in ECE. The 27 participants who answered "YES" described the characteristics they knew about ASD. Sixteen of these teachers described three characteristics, reporting aspects related to communication deficits, changes in social interaction, and restricted or repetitive patterns of behavior and/ or interest. Ten participants described only two out of these three characteristics and one teacher described only persistent deficits in communication as a characteristic she knew on ASD. The authors prepared a classification, based on the description of DSM- $5^{16}$, to standardize the answers obtained (Chart 2).

Chart 2. Knowledge of the characteristics of Autism Spectrum Disorder described by the teachers and categorized in the classification developed by the authors based on the Diagnostic and Statistical Manual of Mental Disorders- 5

\begin{tabular}{|c|c|c|c|}
\hline Classification & DSM-5 Characteristics & N & N \\
\hline \multirow{2}{*}{4 - Complete answer } & $\begin{array}{c}\text { * Communication deficits; } \\
\text { * Change in social interaction; }\end{array}$ & \multirow{2}{*}{$59.25 \%$} \\
\hline 3 & * Restricted and / or repetitive patterns of behavior and interest. & & 10 \\
\hline 2 & Absence of an item from the complete answer. & $37.03 \%$ & 1 \\
\hline 1 & Absence of two items from the complete answer. & $3.70 \%$ & 0 \\
\hline TOTAL & Absence of all items from the complete answer & $0 \%$ & 27 \\
\hline
\end{tabular}

Caption: DSM-5 = Diagnostic and Statistical Manual of Mental Disorders; $N=$ number of participants

It was found that $80 \%(n=4)$ of the teachers who worked in the SEA received the medical report of their students with ASD, followed by $66.7 \%(n=4)$ of the teachers of the SE and $57.1 \%(n=12)$ of the ECE teachers. In total, $62.5 \%(n=20)$ received the students' medical report; $15.6 \%(n=5)$ stated that they were only informed, without having access to the report; and $21.9 \%(n=7)$ stated that they were informed and that the institution did not receive a medical report (the knowledge about ASD was received through reports from family members).
When considering how much the medical report brought benefits to the pedagogical performance, it was found that only three teachers who received the report considered that it helped in their pedagogical performance. 17 participants who received the report stated that it only helped with the knowledge of the diagnosis of ASD and 12 teachers, despite having received the report, did not consider that it added value to their pedagogical performance (Chart 3). 
Chart 3. Consideration regarding assistance in pedagogical performance or knowledge about Autism Spectrum Disorder when receiving the student's medical report

\begin{tabular}{|l|c|c|}
\hline Answer & Participants & Percentage \\
\hline $\begin{array}{l}\text { Received the medical report and considered that it helped in the pedagogical } \\
\text { performance }\end{array}$ & 3 & $9.4 \%$ \\
\hline $\begin{array}{l}\text { Received the medical report and considered that it only helped with the knowledge of } \\
\text { the diagnosis of ASD }\end{array}$ & 17 & $53.1 \%$ \\
\hline $\begin{array}{l}\text { Received the medical report, but did not consider that it added value to the } \\
\text { pedagogical performance }\end{array}$ & 12 & $37.5 \%$ \\
\hline
\end{tabular}

Caption: ASD = Autism Spectrum Disorder

To consider the observation of the teachers about the characteristics of their students with ASD (Question 4), they were asked to list changes related to behavior, socialization, communication, learning, or others. The teachers expressed themselves with specific features, without further explanation or description of the changes mentioned. The authors counted the quantity and aspects of the characteristics that each participant mentioned, enabling the following grouping: The vast majority of teachers, $65.2 \%(n=21)$ stated that they observed difficulties in socialization, communication, behavior, and learning. 15.6\% $(n=5)$ of the professionals reported aggressive and irritating behavior; $12.5 \%(n=4)$ reported attention and concentration difficulties and $6.2 \%(n=2)$ mentioned motor coordination difficulties in their students with ASD.

Chart 4. Knowledge of the characteristics of Autism Spectrum Disorder described by the teachers

\begin{tabular}{|l|c|c|}
\hline ASD Characteristics & $\%$ & N \\
\hline Socialization, communication, behavior and learning difficulties & 65.6 & 21 \\
\hline Aggressiveness and irritation behavior & 15.6 & 5 \\
\hline Attention and concentration difficulties & 12.5 & 4 \\
\hline Motor coordination difficulties & 6.2 & 2 \\
\hline & $100 \%$ & 32 \\
\hline
\end{tabular}

Caption: ASD = Autism Spectrum Disorder; $\mathrm{N}=$ number of participants/

A considerable percentage of the teachers (62.5\%) $(\mathrm{N}=20)$ stated that they considered that their students with ASD had the potential to follow teaching in mainstream school (Question 5). Of the remaining teachers to complete the sample (38.6\%) ( $n=12)$, half did not believe that these students would follow mainstream education and half chose not to answer. Again, although it was an open question (Question 5), the participants chose to answer directly, stating, denying, or not issuing their opinion, without explanations or any deepening to support their answers.

In the question about receiving follow-up or guidance from a specialized professional (Question 6), $68.8 \%(n=22)$ of the teachers stated that they received this collaboration from the rehabilitation team of their students.
Most of the teachers in the sample, $78.1 \%$ $(n=25)$, participated in courses and lectures with content focused on teaching students with ASD (Question 7). Of this total, all teachers in the SEA and SE groups are included and $66.7 \%(n=14)$ of the ECE teachers also participated, while $33.3 \%(n=7)$ did not attend any lecture or course focused on this content.

Of the total sample, 32 teachers, only $28.1 \%$ $(n=9)$ reported that they consider themselves able to work with students with ASD (Question 8), stating that they have sufficient knowledge to promote the effective teaching-learning process for their students with ASD and $78.1 \%(n=25)$ stated that changes and adjustments in the teaching structure are necessary for students with ASD (Question 9), 3.1\% ( $n=1)$ did not consider changes or adjustments necessary; $18.8 \%$ $(n=6)$ did not answer the question. 


\section{DISCUSSION}

The study sample was selected at random, given the interest of the teachers to participate, after the institutions agreed to participate in the research. The participating professionals were all female, belonging to three different areas of expertise: specialized educational assistance, in the SE modality; specialized educational assistance, however developing activities in APAE, in the SEA modality; as well as others teaching in ECE in mainstream classrooms. All working in preschool, according to the inclusion criteria determined by the authors.

The majority of the participating teachers worked in ECE and had an undergraduate degree in Pedagogy. A relevant aspect is the high percentage of teachers who presented a latu sensu postgraduate degree, being the professionals working in SEA and ECE the ones who most presented postgraduate degrees.

When considering that training at the postgraduate level can offer a greater range of subsidies for knowledge and performance with children with ASD, since the curricula of teacher training courses, in their majority, do not promote sufficiently with satisfactory knowledge to develop the pedagogical performance with children with ASD, offering training that is often out of reality and making teachers feel unprepared to teach in this context. The fact that teachers who work in ECE do not present training at the postgraduate level, shows, in the scope of the training of teachers who work with ASD, an important aspect about the education offered to these children in the municipality studied. Several studies have discussed this issue 21-24. It should be noted, however, that even having postgraduate degree, the content learned may not be applied to the daily needs of these teachers when working with students with ASD in the classroom.

A small percentage of the sample, which worked in the context of ECE in a mainstream school, stated that they did not know about ASD. The majority of the teachers stated that they know the characteristics of ASD and adequately described the known aspects. Among the answers, classified from 1 to 4 by the authors, in which 4 was the knowledge of the main characteristics described in the DSM-5 (deficits in communication; changes in social interaction; restricted and/or repetitive patterns of behavior and interest $)^{16}$ and 1 was related to not mentioning any of the 3 basic characteristics of ASD, it was found that a similar percentage of the teachers who work in the context of SEA, SE and ECE were classified in level "4" and " 3 " and only one teacher from ECE was classified at level "2". This teacher mentioned only the characteristic "persistent deficits in communication" related to her knowledge on ASD. No teacher who answered that knew ASD was classified as level "1", that is, all teachers who answered affirmatively had knowledge of at least 1 characteristic that is predicted in cases of ASD.

The analysis of the excerpt above allows us to conclude that even being low the percentage of professionals who did not know the main characteristics of ASD, in the sample presented here, this is a worrisome factor since the availability of information about ASD is extensive in literature, in digital media, in training courses and in frequent lectures on this theme ${ }^{25,26}$. Thus, even considering the recent growth of children diagnosed with ASD and their inclusion in mainstream classes, especially over the last decade, from a practical point of view, previous steps, such as teacher training, including continuing education, need to be reviewed and analyzed so that the evolution process of school inclusion presents a solid basis, with a construct to provide support so that teachers working in this context can develop pedagogical practices that fully contemplate the understanding of learners with ASD $^{27-29}$.

All teachers participating in the study, in the period in which they filled out the questionnaire, worked with at least one student with ASD in their classroom (inclusion criteria), regardless of the context ECE, SE or SEA. An alarming fact is that although the vast majority of teachers had access to their student's ASD medical report (most of them belonging to the context of SEA), only some of the interviewees believed that the access to the medical report brought benefits, helped in the teaching practice with students with ASD. It should be noted that even having access to the medical report, it should not be used as a manual for teachers to work with children with ASD, since even though they are on the Autistic Spectrum each child has its development and particularities, requiring different directions and adaptations for each individual. However, the absence and the lack of knowledge of this document, by the teachers, can compromise the pedagogical performance, since many cases of ASD are accompanied by comorbidities that can directly interfere in the child's educational development ${ }^{30,31}$.

Another point to be highlighted is that, generally, in the school context, only the medical report is requested, once with it it is possible to guarantee some rights of the child with ASD. It is noteworthy that the teacher's 
access to the reports of the interdisciplinary team (speech therapist, psychologist, occupational therapist, among other professionals) of the student with ASD is crucial. Thus, considering that the majority of teachers stated that they receive follow-up or guidance from a specialized professional, it is emphasized that it is the professionals' responsibility, both in the area of rehabilitation/stimulation, as well as in the academic area (teacher, principal, pedagogical coordinator), to recognize the importance of the teamwork, including the school, to develop the planning of skills that need to be stimulated and developed individually for each student with ASD.

The teachers, in their majority, identified and informed characteristics of their students with ASD related to changes in socialization, communication, behavior, and learning, in addition to some, in a lesser extent, affirming aggressive and irritable behaviors, attention and concentration deficits, and also difficulty in fine motor coordination. This finding reinforces the need for the professional team to guide teachers in their work with each student, considering their individuality and development.

Over half of the participating teachers informed that they believe that their students with ASD have the potential to follow mainstream education. Six teachers said they did not believe in this possibility and six chose not to answer. After verifying this result, it would be interesting to know the reasons why this minority chose not to answer or not to believe in the possibility of their students develop in the context of mainstream education. Two major spheres can be analyzed, related to the child's level of commitment to ASD or the education system, with locks or little effective assistance to children who need guidance and adaptations to promote their learning.

Almost all teachers said they had already participated in courses and lectures focused on ASD, including in this percentage all teachers from SE and SEA and some from ECE. Even with this result, when asked about whether they are able to promote an effective learning process for their students with ASD, only a few answered positively. This result refers to the reasoning of the interfering factors in the learning process of children with ASD, which are not only focused on their characteristics, but also on the training of the entire team that works in their development process, including the school environment. The literature analyzes the self-efficacy of teachers in this scenario $^{32-34}$.
Teachers' perception and opinion, regarding the need for changes and adjustments in the teaching structure to meet the characteristics of students with ASD, was verified. One teacher answered negatively to this need and six teachers chose not to answer. Again, there is a need to investigate further why these teachers did not have an opinion. Hypotheses arise, among them the lack of knowledge of what would be changes and adjustments in the teaching structure. In this sense, the need to invest in the continuing education of teachers who work with students with ASD is highlighted, as well as to analyze the other factors (investment in infrastructure, teaching materials, technologies, etc.), interfering in the teaching-learning process of this population, to guarantee access to quality education.

Knowing that school success can also bring benefits to the personal and social development of the individual with ASD, and it permeates and is influenced by pedagogical performance, good school development, especially in the first school years, which is fundamental not only for school success, but also for the daily life of children with ASD, depends on pedagogical performance in line with national and international inclusive policies.

\section{CONCLUSION}

The panorama of the pedagogical context in mainstream public education for students with ASD enrolled in preschool in the municipality studied needs reflection. It was concluded that it is necessary to implement public policies and provide information on characteristics of ASD, as well as training courses for teachers and other school staff professionals who deal with students with ASD. A reduced interdisciplinarity among the team of professionals who work directly and individually with students with ASD and teachers was seen. With adjustments considering these principles, teachers would be able to feel better prepared to promote the effective teaching-learning process for their students with ASD.

\section{ACKNOWLEDGMENT}

This study was financed in part by the Coordenação de Aperfeiçoamento de Pessoal de Nível Superior Brasil (CAPES) - Finance Code 001. 


\section{REFERENCES}

1. Silva Neto AO, Ávila EG, Sales TRR, Amorim SS, Nunes AKF, Santos VM. Educação inclusiva: uma escola para todos. Rev Edu Esp [journal on the internet]. 2018 [accessed on 2020 Jul 2]; 31(60):81-92. Available at: https://doi. org/10.5902/1984686X24091

2. Teixeira MN. Conflito social pela educação de qualidade: uma reflexão sobre os sistemas de avaliação educacional. InterSciencePlace [journal on the internet]. 2015 [accessed on 2020 Jul 2]; 2(10):118-34. Available at: http://dx.doi. org/10.6020/1679-9844/v10n2a7

3. Brasil. Constituição da República Federativa do Brasil. Brasília: Imprensa Oficial, 1988. [accessed on $2020 \mathrm{Jul}$ 2]. Available at: http://www.planalto. gov.br/ccivil_03/constituicao/constituicao.htm

4. Kassar MCM. Percursos da constituição de uma política brasileira de educação especial inclusiva. Rev. bras. educ. espec. [journal on the internet]. 2011. [accessed on 2020 Jul 19]; 17(1):41-58. Available at: https://doi.org/10.1590/ S1413-65382011000400005.

5. Silva MOE. Educação inclusiva: um novo paradigma de Escola. Rev. Lusóf Educ. Esp [journal on the internet]. 2011 [accessed on 2020 Jul 2]; 19(19):119-34. Available at: http://www. scielo.mec.pt/scielo.php?script =sci_arttext\&pid= S164572502011000300008\&lng $=p t \& n r m=$ iso

6. Glat R, Fernandes EM. Da educação segregada à educação inclusiva: uma breve reflexão sobre os paradigmas educacionais no contexto da educação especial brasileira. Revista Inclusão [journal on the internet]. 2005 [accessed on $2020 \mathrm{Jul}$ 19]; 1 (1):35-9. Available at: http://portal.mec.gov.br/component/ content/article?id=12626: revista-inclusao-nd1 .

7. Brasil. Política Nacional de Educação Especial na Perspectiva da Educação Inclusiva. Brasília, DF, jan. 2008a. [Documento elaborado pelo Grupo de Trabalho nomeado pela portaria n. 555/2007, prorrogada pela portaria n. 948/2007, entregue ao ministro da Educação em 7 de janeiro de 2008]. [accessed on $2020 \mathrm{Jul}$ 2]. Available at: http://portal. mec.gov.br/arquivos/pdf/politicaeducespecial.pdf
8. Brasil. Lei no 12.764, de 27 de Dezembro de 2012. Institui a Política Nacional de Proteção dos Direitos da Pessoa com Transtorno do Espectro Autista; e altera o § 3ㅇ do art. 98 da Lei $n$ ㅇ 8.112, de 11 de dezembro de 1990. [accessed on 2020 Jul 2]. Available at: http://www.planalto.gov.br/ccivil_03/_ ato2011-2014/2012/lei//12764.htm

9. Brasil. Lei no 13.146, de 06 de julho de 2015 . Institui a lei brasileira de inclusão da pessoa com deficiência (Estatuto da pessoa com deficiência). Diário Oficial da União, Brasília, DF, 7 jul. 2015. [accessed on $2020 \mathrm{Jul}$ 2]. Available at: http://www. planalto.gov.br/ccivil_03/_ato2015-2018/2015/lei/ I13146.htm

10. Brasil: Instituto Nacional de Estudos e Pesquisas Educacionais Anísio Teixeira (INEP). Censo Escolar da Educação Básica 2016 - Notas Estatísticas. [accessed on 2020 Jun 21]. Available at: http:// download.inep.gov.br/educacao_basica/censo_ escolar/notas_estatisticas/2017/notas_estatisticas _ censo_escolar_da_educacao_basica_2016.pdf

11. Dall'Acqua MJC, Vitaliano CR. Algumas reflexões sobre o processo inclusivo em nosso contexto educacional. In: Vitaliano CR, editor. Formação de professores para a inclusão de alunos com necessidades educacionais especiais. Londrina: EDUEL; 2010. p. 17-31.

12. Ferreira JR, Ferreira MCC. Sobre inclusão, políticas públicas e práticas pedagógicas. In: Góes MCR, Laplane ALF, editors. Políticas e práticas de educação inclusiva. Campinas: Autores Associados; 2013. p. 21-46.

13. Santos JRR, Midlej MMBC. Uma reflexão sobre o contexto educacional contemporâneo. Psicol. educ. [journal on the internet]. 2019. [accessed on 2020 Jul 18]; 48: 77-86. Available at: http://dx.doi. org/10.5935/2175-3520.20190009.

14. Sousa LM. Educação especial no Brasil: o que a história nos conta sobre a educação da pessoa com deficiência. R. Bibliomar. [journal on the internet] 2020. [accessed on $2020 \mathrm{Jul}$ 18]; 19 (1): 159-73. Available at: http://www.periodicoseletronicos. ufma.br/index.php/bibliomar/article/view/13636.

15. Bernado ES, Christovão AC. Tempo de escola e gestão democrática: o Programa Mais Educação e o IDEB em busca da qualidade da educação. Educ. Real. [journal on the internet]. 2016. [accessed on 2020 Jul 2]; 41 (4):1113-40. Available at: https://doi. org/10.1590/2175-623660597. 
16. American Psychiatric Association. Diagnostic and Statistical Manual of Mental Disorders. 5th ed. Arlington, VA: Author; 2013.

17. Brasil. Ministério da Educação. Lei de Diretrizes e Bases da Educação Nacional. LDB 9.394, de 20 de dezembro de 1996. Available at: http://www. planalto.gov.br/ccivil_03/leis/19394.htm

18. Torres JP, Mendes EG. Atitudes sociais e formação inicial de professores para a educação especial. Rev. bras. educ. espec. [journal on the internet ] 2019. [accessed on $2020 \mathrm{Jul} \mathrm{18];}$ 25(4):765-80. Available at: https://doi.org/10.1590/ s1413-65382519000400014.

19. Pletsch D. A formação de professores para a educação inclusiva: legislação, diretrizes políticas e resultados de pesquisas. Educar em revista. [journal on the internet] 2009. [accessed on 2019 Jul 18]; 25(33):143-56. Available at: https://doi. org/10.1590/S0104-40602009000100010

20. Manzini EJ. Política de educação especial: considerações sobre público-alvo, formação de professores e financiamento. RPGE. [journal on the internet] 2018. [accessed on 2020 Jul 18]; 22(2):810-24. Available at: https://periodicos.fclar. unesp.br/rpge/article/view/11914

21. Giroto CRM, Castro RM. A formação de professores para a educação inclusiva: alguns aspectos de um trabalho colaborativo entre pesquisadores e professores da Educação Infantil. Rev Educ Esp. [journal on the internet]. 2011. [accessed on 2020 Jul 2]; 24(41):441-51. Available at: https://www. redalyc.org/pdf/3131/313127403009.pdf

22. Silveira KA, Enumo SRF, Rosa EM. Concepções de professores sobre inclusão escolar e interações em ambiente inclusivo: uma revisão da literatura. Rev Bras Educ Esp. [journal on the internet]. 2012. [accessed on 2020 Jul 2]; 18(4):695708. Available at: http://dx.doi.org/10.1590/ S1413-65382012000400011

23. Favoretto NC, Lamônica DAC. Conhecimentos e necessidades dos professores em relação aos transtornos do espectro autístico. Rev. bras. educ. espec. [journal on the internet]. 2014. [accessed on 2020 Jul 2]; 20(1):103-16. Available at: http://dx.doi. org/10.1590/S1413-65382014000100008.
24. Garnica TPB, Cavalheiro GCS, Quaglio EMH, Capellini VLMF. O Saber fazer na formação de professores para a inclusão escolar: um levantamento bibliográfico. Rev Ens \& Pesq. [journal on the internet]. 2016. [accessed on 2020 Jul 2]; 14(02):58-87. Available at: http://periodicos. unespar.edu.br/index.php/ensinoepesquisa/article/ view/970

25. Khoury LP, Teixeira MCTV, Carreiro LRR, Schwartzman JS, Ribeiro AF, Cantieri CN. Manejo comportamental de crianças com transtornos do espectro do autismo em condição de inclusão escolar: guia de orientação a professores. [accessed on $2020 \mathrm{Jul}$ 2]. Available at: http://portal. educacao.rs.gov.br/Portals/1/Files/3155.pdf

26. Moral A, Shimabukuro EH, Zink AG, Molina EC. Entendendo o autismo. [accessed on $2020 \mathrm{Jul}$ 2]. Available at: https://www.iag.usp.br/ eder/ autismo/Cartilha-Autismo-final.pdf.

27. Schmidt C, Nunes DRP, Pereira DM, Oliveira VF, Nuernberg AH, Kubaski C. Inclusão escolar e autismo: uma análise da percepção docente e práticas pedagógicas. Psicol. Teor. prat. [journal on the internet]. 2016. [accessed on 2020 Jul 2]; 18(1):222-35. Available at: http:// pepsic.bvsalud.org/scielo. php? script $=$ sci arttext\&pid=S1516-36872016000100017\&lng $=p t \&$ tlng $=$ pt.

28. Pasian MS, Mendes EG, Cia F. Atendimento educacional especializado: aspectos da formação do professor. Cadernos de Pesquisa. [journal on the internet]. 2017. [accessed on $2020 \mathrm{Jul}$ 2]; 47(165):964-81. Available at: https://doi. org/10.1590/198053144242.

29. Nery M, Rech T. Inclusão na contemporaneidade: possibilidades para pensarmos a docência e a aprendizagem. Rev Sem Edu Cruz Alta. [journal on the internet], 2020. [accessed on $2020 \mathrm{Jul} \mathrm{19]}$; 7(01):27-35. Available at: http://www.exatasnaweb. com.br/revista/index.php/anais/article/view/744.

30. Gotham K, Brunwasser SM, Lord C. Depressive and anxiety symptom trajectories from school age through young adulthood in samples with Autism Spectrum Disorder and developmental delay. J Am Acad Child Adolesc Psychiatry. [journal on the internet]. 2015. [accessed on 2020 Jul 2]; 54(5):369-76. Available at: https://doi.org/10.1016/j. jaac.2015.02.005 
31. Marchezan J, Riesgo RS. Comorbidades dos transtornos do espectro autista. In: Rotta NT, Ohlweiler L, Riesgo RS, editors. Transtornos de aprendizagem: abordagem neurobiológica e multidisciplinar. 2 ed. Porto Alegre: Artmed; 2016. p. 378-92.

32. Martins BA, Chacon MCM. Autoeficácia docente e educação especial: revisão da produção de conhecimento nacional e internacional com ênfase na formação de professores. Rev. Edu. Esp. [journal on the internet]. 2019. [accessed on 2020 Jul 19]; 32:1-22. Available at: http://dx.doi. org/10.5902/1984686X35883.

33. Lima CT, Lopes JCV, Andrade HA, Freitas, AV, Reis RM. Educação inclusiva no colégio militar de Salvador: a ótica do corpo docente sobre a inclusão escolar. Interfaces Científica. [journal on the internet]. 2020. [accessed on $2020 \mathrm{Jul}$ 19]; 8(3):304-21. Available at: http://dx.doi. org/10.17564/2316-3828.2020v8n3p304-321.

34. Melo JGS, Coutinho DJG. Educação infantil: métodos e estratégias para inclusão. Revista Espacios [journal on the internet]. 2020. [accessed on 2020 Jul 19]; 41(18):4-13. Available at: https://www.revistaespacios.com/a20v41n18/ a20v41n18p04.pdf. 


\section{ATTACHMENT}

\section{Questionnaire for the Teachers}

\section{Block 1 - Characterization of the Participant}

1) Name:

2) Age:

3) Gender: ( ) Male ( ) Female ( ) Others

4) Academic background, please list all if there is more than one.

5) Academic background - postgraduate, please list all if there is more than one.

6) In which teaching context are you currently working (more than one answer can be chosen):

( ) Early Childhood Education (ECE)

() Special Education (SP)

() Specialized Educational Assistance (SEA)
Block 2 - Performance with students with Autism Spectrum Disorder (ASD)

1) Do you know the main characteristics of ASD? If so, list them please.

( ) Yes ( ) No

Characteristics:

2) Did you receive any medical report from your student (s) with ASD?

A () Yes B () No C () I was just informed by the school that the student has a medical report of ASD

3) The medical report of your student (s) with ASD:

() Helped in professional performance (there were recommendations on how to act professionally in relation to this student and his/her specific behavioral characteristics).

() It helped in professional performance because, from the diagnosis, it was possible to develop teaching practice in order to consider the needs of that student.

( ) Helped, but did not offer recommendations on how to act with these students.

( ) Did not help and did not help.

Other:

4) What changes in behavior, socialization, communication, and learning do you observe in your student (s) with ASD?

5) Do you consider that this student (s) has the potential to follow the teaching in a regular school? ( )Yes ( )No 6) Do you receive follow-up/guidance from a specialized professional while working with your ASD student (s)?

7) Do you participate or have participated in specific courses, lectures, or training with content focused on teaching students with ASD?

( ) Yes ( ) No

8) Do you consider that you have sufficient knowledge to promote an effective teaching-learning process to your student (s) with ASD?

( ) Yes ( ) No

9) Do you believe there is a need for changes/adjustments in the teaching structure, from the contents taught daily to the evaluation process, for the student (s) with ASD?

( ) Yes ( ) No 